\title{
Nilai Religius Pada Cerpen Ciumlah Aku di Ujung Subuh Karya Hamzah Puadi Ilyas
}

\author{
Deasy Wahyu Hidayati ${ }^{*}$ \\ ${ }^{* 1}$ Universitas Muhammadiyah \\ Prof. DR. HAMKA, Jakarta \\ Timur, Jakarta, Indonesia \\ *email: \\ hidayatideasy@gmail.com
}

\section{Received: 29 Maret 2021}

Accepted: 1 April 2021

Published: 1 April 2021

doi: $10.22236 /$ imajeri.v3i2.6719

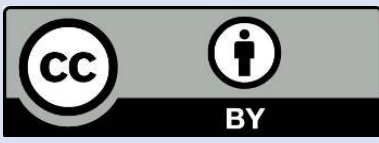

(C) 2021 Oleh authors. Lisensi Imajeri: Jurnal Pendidikan Bahasa dan Sastra Indonesia, Uhamka, Jakarta. Artikel ini bersifat open access yang didistribusikan di bawah syarat dan ketentuan Creative Commons Attribution (CC-BY) license. (http://creativecommons.org/licens es/by/4.0/)

\begin{abstract}
Abstrak
Cerita pendek memiliki peran untuk membentuk nilai karena setiap cerita memiliki nilai yang bermanfaat bagi pembacanya. Tujuan penelitian ini mengetahui gambaran mengenai unsur atau nilai-nilai religi yang terdapat dalam cerpen Ciumlah Aku di Ujung Subuh Karya Hamzah Puadi Ilyas. Metode dalam penelitian ini adalah metode penelitian kualitatif deskripsi. Nilai religius dalam cerpen Ciumlah Aku di Ujung Subuh Karya Hamzah Puadi Ilyas menunjukkan terdapat nilai religius dalam aspek kepercayaan kepada Allah meliputi percaya adanya malaikat, hari kiamat, bahtera nabi, dan percaya al-Quran dan hadis; nilai religius dalam aspek rasa takjub akan keagungan Tuhan meliputi takjub akan aroma durjana, kekuasaan tuhan, dan penciptaan alam semesta; nilai religius dalam aspek getaran hati nurani pribadi meliputi getaran hati akan syukur, tangisan peristiwa, ingatan dulu, dan cita-cita; nilai religius dalam aspek sikap personal meliputi sikap beribadah, bersujud, beristigfar, berdzikir, dan membaca alQuran/juz-amma; dan nilai religius dalam aspek intimidasi jiwa meliputi intimidasi jiwa dari karma, proses inti kematian, dan proses pencabutan nyawa. Berdasarkan hasil penelitian ini, dapat diketahui juga bahwa nilai religius yang paling banyak muncul dalam cerpen Ciumlah Aku di Ujung Subuh Karya Hamzah Puadi Ilyas tersebut yaitu sikap personal. Kata kunci: Nilai; Religius; Cerpen; SMA

\section{Abstract}

Short stories have a role to form value because each story has value that is beneficial to its readers. The purpose of this study is to find a description of the elements or religious values contained in the short stories of Kiss Aku di Ujung Subuh by Hamzah Puadi Ilyas. The method in this study is a descriptive qualitative research method. The religious value in the short story Kiss Aku di Ujung Subuh by Hamzah Puadi Ilyas shows that there is religious value in the aspect of belief in Allah, including believing in angels, the Day of Judgment, the prophet's ark, and believing in the Koran and hadiths; religious value in the aspect of awe of the majesty of God includes amazement at the aroma of wickedness, the power of God, and the creation of the universe; religious values in the aspect of the vibration of a personal conscience include a heart vibration of gratitude, cries of events, past memories, and dreams; religious values in the aspect of personal attitudes include the attitude of worship, prostrate, makeistigfar, dhikr, and read the Koran / juz-amma; and religious values in the aspect of mental intimidation include intimidation of the soul from karma, the core process of death, and the process of taking one's life. Based on the results of this study, it can also be seen that the religious value that appears most in the short stories of Ciinum Aku di Ujung Subuh by Hamzah Puadi Ilyas is personal attitude.
\end{abstract}

Keywords: Score; Religious; Short story; High school 


\section{PENDAHULUAN}

Berbicara mengenai sastra tidak akan lepas dari karya manusia. Karya sastra tersebut, diciptakan untuk dibaca dan dinikmati oleh pembaca. Dengan menikmati karya sastra, pembaca dapat menerima beberapa manfaat berupa pengetahuan dan pengalaman yang mendalam tentang manusia. Sastra harus mampu melahirkan sesuatu yang bermanfaat dan berguna sesuai dengan tujuan penulisannya (Wulandari, 2015; Rondiyah, dkk, 2017). Dalam hal ini, penulis dituntut untuk lebih kreatif dalam memanfaatkan medium bahasa untuk memberikan berbagai informasi yang berguna bagi pembaca.

Karya sastra bukan hanya alat untuk menyampaikan pesan, melainkan suatu refleksi kehidupan nyata bagi pembaca dalam menafsirkan nilai-nilai kebenaran yang sukar untuk dipahami (Kesambamula \& Semi, 2013:1-2). Karya sastra dapat dijadikan sebagai ungkapan atau gambaran tentang realita kehidupan yang diwujudkan ke dalam bentuk bahasa yang mengandung nilai-nilai kehidupan (Kurniawan, 2011: Hidaya, 2018). Agar nilai-nilai kehidupan tersebut dapat dirasakan oleh pembaca, maka perlu adanya penananaman kecintaan terhadap sastra. Hal ini dilakukan agar kemudian hari pembaca dapat mampu mengekspresikan, mengapresiasikan dan memahami sebuah karya sastra.

Salah satu karya sastra yang dapat dinikmati oleh pembaca ialah cerita pendek (cerpen). Cerita pendek (cerpen) adalah cerita yang membatasi diri dalam membahas salah satu unsur fiksi dalam aspeknya yang terkecil. Kependekan sebuah cerita pendek bukan karena bentuknya yang jauh lebih pendek dari novel, melainkan karena aspek masalahnya yang sangat dibatasi (Nurgiantoro, 2013:12; Mansur, 2018). Pada cerpen, pengarang bebas cerita berdasarkan nilainilai kehidupan yang dapat menjadi inspirasi pembaca (Nurgiantoro, 2013: 12; Faizah \& Bengat, 2017).

Persoalan yang diangkat dalam cerpen mengandung nilai-nilai kehidupan yang begitu unik dan menarik, sehingga cerita dalam cerpen mampu memberikan makna kehidupan yang dalam. Peristiwa-peristiwa yang dilakukan dalam cerpen terkadang mirip dengan pengalaman yang pernah pembaca alami karena pengarang memasukkan gambaran masyarakat dan nila-nilai kehidupan di dalamnya. Nilai-nilai kehidupan serta gambaran masyarakat dalam cerpen kuat dan tidak kalah menariknya dengan pengukapan dalam sebuah novel, meskipun dalam sebuah cerpen hanya dicerikatan bagian kecil saja yang mewakili seluruh kejadian.

Salah satu permasalahan yang dikaji dalam cerpen ialah masalah religius. Dalam hal ini, nilainilai religius menjadi suatu hal yang sangat penting sebagai pedoman dalam mengatur dan menjalani kehidupan. Nilai religius menjadi nilai yang bersumber dari ajaran agama. Nilai religius adalah perilaku seseorang yang sesuai dengan ajaran agama (Jauhari, 2010: 27). Nilai religius sebagai cerminan dari iman dan takwa kepada Tuhan Yang Maha Esa diwujudkan secara utuh dalam bentuk ibadah sesuai dengan agama dan keyakinan masing-masing.

Seorang yang religius dapat diartikan sebagai manusia yang berarti, yang berhati nurani serius, saleh, teliti, dan penuh dengan pertimbangan spiritual. Nilai religius sangat mempengaruhi manusia dalam bertingkah laku dan bersikap. Seseorang yang tingkah laku dan sikapnya baik maka orang tersebut memiliki nilai religius yang baik pula kepada agamanya (Anasrullah, 2018; Lathief, 2008:175).

Nilai religius membicarakan segala perasaan batin yang ada hubungannya dengan Tuhan, perasaan kecintaan dan kekuasaan Tuhan. Dalam hal ini, perasaan tersbut dapat diaktulisasikan ke dalam beberapa aspek religi yang meliputi kepercayaan kepada Allah, rasa takjub akan 
keagungan Tuhan, getaran hati nurani pribadi, sikap personal yang merupakan misteri bagi orang lain dan intimidasi jiwa (Hartoko, 1990:187).

Dalam kumpulan cerpen tersebut, pengarang memadukan antara seni sastra dengan religi, karena bagimana pun pada dasarnya religi tidak dapat dipisahkan dari segala aspek kehidupan. Dengan menganalisis cerpen tersebut diharapkan dapat memotivasi pengajar sastra di SMA dalam pembelajaran sastra khususnya cerpen, secara keratif dan apresiatif. Selain itu, guru dapat menanamkan religiusitas kepada siswa. Dengan demikian, diharapkan dapat membangkitkan minat dan memperluas wawasan siswa dalam mempelajari sastra, khususnya cerpen, serta dapat membantu guru dalam membentuk generasi muda yang tidak hanya cerdas, tetapi juga religius.

Penelitian terdahulu tentang nilai religi pada cerpen dilakukan oleh Sari (2019) dengan judul "Nilai-nilai religius dalam kumpulan cerpen Robohnya Surau Kami karya A.A. Navis dan implikasinya terhadap pembelajaran sastra di SMA” dengan metode deskriptif kualitatif. Hasil penelitian menunjukkan bahwa kumpulan cerpen Robohnya Surau Kami karya A.A Navis mengandung nilai-nilai religius. Nilai religius yang terkandung dalam kumpulan cerpen Robohnya Surau Kami karya A.A. Navis meliputi tauhid, fikih, dan akhlak. Tauhid terdiri atas iman kepada Allah, takwa kepada-Nya, dan tobat. Fikih terdiri atas halal, haram, makruh, mubah, dan sunah. Akhlak meliputi akhlak baik dan akhlak buruk.

Selain Sari (2019), Suharni (2017) juga melakukan penelitian terkait dengan judul "Nilai religius pada kumpulan cerpen Pelajaran Pertama Bagi Calon Politisi karya Kuntowijoyo: kajian sosiologi sastra." Metode penelitian yang digunakan adalah metode deskriptif, berbentuk kualitatif. Hasil penelitian ini menunjukkan bahwa (1) nilai religius dilihat dari segi agama Islam meliputi tawakal (Jangan Dikubur sebagai Pahlawan), tauhid (Tawanan dan Pelajaran Pertama Bagi Calon Politisi), tasamuh (Lurah), sembahyang (Rumah yang Terbakar dan RT 03 RW 22 Jalan Belimbing atau Jalan "Asmaradana”). (2) Nilai religius dilihat dari segi kebudayaan Jawa meliputi kepercayaan (Laki-laki yang Kawin dengan Peri; Lurah; Pistol Perdamaian; Anjinganjing Menyerang Kuburan; Rumah yang Terbakar; Jangan Dikubur sebagai Pahlawan; Tawanan; JL Kembang Setaman, JL Kembang Boreh, JL Kembang Desa, dan lain-lain.

Dalam penelitian yang dilakukan oleh Sari (2019) dan Suharni (2017) sudah relevan dengan penelitian yang dilakukan oleh penulis. Dalam penelitian ini memiliki kesamaan yaitu sama menggunakan metode deskriptif kualitatif untuk menganalisis nilai religi pada cerpen. Namun, penelitian yang dilakukan peneliti cukup berbeda, sebab peneliti meninjau nilai religi dari segi kepercayaan kepada Allah, rasa takjub akan keagungan Tuhan, getaran hati nurani pribadi, sikap personal yang merupakan misteri bagi orang lain dan intimidasi jiwa.

Cerpen religius memberikan implikasi bagi pembelajaran sastra di sekolah. Salah satunya cerpen Ciumlah Aku di Ujung Subuh Karya Hamzah Puadi Ilyas. Cerpen ini di dalam beberapa subjudulnya memiliki cerita yang terkandung nilai-nilai religi. Salah satu alasan penulis memilih cerpen Ciumlah Aku di Ujung Subuh Karya Hamzah Puadi Ilyas sebagai materi peneliti adalah karena cerpen tersebut memiliki pesan religi yang mendalam bagi pembaca, terutama bagi siswa SMP yang tumbuh kembang menjadi remaja. Dari cerpen tersebut, pembaca mampu memetik nilai religi yang ingin disampaikan pengarang walaupun cerita tetapi mudah dipahami serta dimengerti oleh para pembaca.

Fokus Permasalahan yang menarik untuk dikaji dalam penelitian ini adalah nilai-nilai religius apa saja yang terdapat dalam cerpen Ciumlah Aku di Ujung Subuh Karya Hamzah Puadi Ilyas? Religius di sini dikaitkan dengan dengan hal yang behubungan dengan manusia dengan Tuhan 
serta manusia dengan manusia, seperti kepercayaan kepada Allah, rasa takjub akan keagungan Tuhan, getaran hati nurani pribadi, sikap personal yang merupakan misteri bagi orang lain dan intimidasi jiwa. Hal ini sesuai dengan tujuan penelitian ini yaitu mengetahui gambaran mengenai unsur atau nilai-nilai religi yang terdapat dalam cerpen Ciumlah Aku di Ujung Subuh Karya Hamzah Puadi Ilyas.

\section{METODE}

Metode yang digunakan dalam penelitian ini yaitu penelitian kualitatif deskripsi. Penelitian kualitatif deskripsi, artinya yang dianalisis dan hasil analisinya berbentuk deskripsi, tidak berupa angka atau koegisien tentang hubungan variabel (Aminuddin, 1990:16). Dalam penelitian ini semata-mata hanya berdasarkan pada fakta dan data atau fenomena yang secara empiris mendukung fakta. Dengan metode deskriptif kualitatif, peneliti hanya menganalisis data berdasarkan unsur-unsur penelitian, kemudian memaparkan, dan menyimpulkannya.

Objek penelitian ini adalah cerpen Ciumlah Aku di Ujung Subuh Karya Hamzah Puadi Ilyas serta implikasinya dalam pembelajaran apresiasi sastra di SMP. Penelitian ini difokuskan pada unsur-unsur sastra dalam hal ini unsur nilai-nilai religi yang ditinjau dari segi kepercayaan kepada Allah, rasa takjub akan keagungan Tuhan, getaran hati nurani pribadi, sikap personal yang merupakan misteri bagi orang lain dan intimidasi jiwa yang terdapat dalam cerpen Ciumlah Aku di Ujung Subuh Karya Hamzah Puadi Ilyas.

Teknik pengumpulan data yang digunakan dalam penelitian ini yaitu teknik content analysis dan metode analisis dokumen. (Nuryatin, 2017) Pengumpulan data melalui teknik pustaka dilakukan dengan cara membaca cerpen Ciumlah Aku di Ujung Subuh Karya Hamzah Puadi Ilyas berulang-ulang, mengutip setiap kalimat dan paragraf yang mengandung unsur nilai religi, mengutip setiap kalimat yang mengandung unsur nilai religi masing-masing: unsur kepercayaan kepada Allah, rasa takjub akan keagungan Tuhan, getaran hati nurani pribadi, sikap personal, dan intimidasi jiwa dan mengumpulkan data-data dari sumber data tertulis. Selanjutnya sumber tertulis itu dilakukan pembacaan dengan seksama lalu dipilih yang relevan sebagai data yang akan dianalisis.

\section{HASIL DAN PEMBAHASAN}

Data Penelitian ini diperoleh dari cerpen Ciumlah Aku di Ujung Subuh Karya Hamzah Puadi Ilyas yang berjumlah 237 halaman. Penelitian ini menggunakan deskriptif kualitatif. Penelitian ini difokuskan pada unsur-unsur sastra dalam hal ini unsur nilai-nilai religi yang terdapat dalam cerpen Ciumlah Aku di Ujung Subuh Karya Hamzah Puadi Ilyas.

Data diambil dari kalimat-kalimat dan paragraf-paragraf yang mengandung unsur-unsur/nilainilai religi yang akan diteliti. Unsur-unsur yang akan diteliti yaitu nilai-nilai religius. Nilai-nilai religius yang akan diteliti adalah kepercayaan kepada Allah, rasa takjub akan keagungan Tuhan, getaran hati nurani pribadi, sikap personal yang merupakan misteri bagi orang lain dan intimidasi jiwa. 
Tabel 1. Analisis Nilai Religius

Pada Cerpen Ciumlah Aku di Ujung Subuh Karya Hamzah Puadi Ilyas

\begin{tabular}{|c|c|c|c|}
\hline NO & NILAI RELIGIUS & $\begin{array}{c}\text { JUMLAH } \\
\text { ANALISIS }\end{array}$ & KATEGORI \\
\hline 1 & Kepercayaan kepada Allah & 19 buah & $\begin{array}{l}\text { Percaya adanya malaikat, hari kiamat, } \\
\text { bahtera nabi, al-Quran dan hadis. }\end{array}$ \\
\hline 2 & Rasa takjub akan keagungan Tuhan & 8 buah & $\begin{array}{l}\text { Takjub akan aroma durjana, kekuasaan } \\
\text { Tuhan, penciptaan alam semesta }\end{array}$ \\
\hline 3 & Getaran hati nurani pribadi & 7 buah & $\begin{array}{l}\text { Getaran hati akan syukur, tangisan } \\
\text { peristiwa, ingatan dulu, cita-cita }\end{array}$ \\
\hline 4 & Sikap personal & 21 buah & $\begin{array}{l}\text { Sikap beribadah, bersujud, beristigfar, } \\
\text { berdzikir, membaca al-Quran/Juz-Amma }\end{array}$ \\
\hline 5 & Intimidasi jiwa & 5 buah & $\begin{array}{l}\text { Intimidasi jiwa dari karma, proses inti } \\
\text { kematian, proses pencabutan nyawa }\end{array}$ \\
\hline
\end{tabular}

Penulis menganalisis terdapat beragam macam nilai religius pada cerpen Ciumlah Aku di Ujung Subuh Karya Hamzah Puadi Ilyas, baik yang dilihat sebagai kepercayaan kepada Allah, rasa takjub akan keagungan Tuhan, getaran hati nurani pribadi, sikap personal yang merupakan misteri bagi orang lain dan intimidasi jiwa. Hal ini dapat kita temui dari beberapa penggalan kutipan dalam cerpen Ciumlah Aku di Ujung Subuh Karya Hamzah Puadi Ilyas yang mampu menggambarkan nilai religi tersebut.

Analisis nilai religi yang dilihat sebagai kepercayaan kepada Allah dalam Cerpen Ciumlah Aku di Ujung Subuh Karya Hamzah Puadi Ilyas

[1] Malaikat pencabut nyawa datang mendekat. Jubah panjangnya yang bergerak tak menimbulkan suara. Tapi, rona wajahnya kini tak lagi menakutkan. Bibirnya seperti mengulum senyum..... (CAUS, 2008:56)

Kutipan di atas menunjukan bahwa penulis menjelaskan nilai religi sebagai kepercayaan kepada Allah yaitu adanya kepercayaan mengenai adanya malaikat pencabut nyawa yang menandakan bahwa dirinya percaya suatu hari akan bertemu dengan malaikat pencabut nyawa dalam detik terakhirnya.

[2] "Sumpah! Aku melihatnya dengan mata kepalaku sendiri." Kata Najib masih dengan mimic ketakutan. "Ada bahtera Nabi Nuh yang sedang terombang-ambing di luar sana. Seluruh penumpangnya berteriak minta tolong. Daerah mereka baru saja dilanda bnjir besar. Banjir kutukan. Aku juga mendengar jerit anak Nabi Nuh yang lari ke puncak bukit. Bukit itu pun tenggelam. Oh, Tuhan, tubuhnya ditelan air bah. Ku lihat tangannya menggapai-gapai di uadara. Tidak... tidaaaaak." (CAUS, 2008:133)

Kutipan di atas menunjukan bahwa penulis menjelaskan nilai religi sebagai kepercayaan kepada Allah yaitu kepercayaan mengenai bahtera Nabi Nuh yang menandakan bahwa dirinya percaya akan kenabian yang dulu pernah terjadi dan telah diriwayatkan melalui al-Quran dan hadis. Beberapa di antara mereka, anak Nabi Nuh sendiri yang tidak percaya dan durhaka kepada Nabi Nuh sehingga ia mati tenggelam dilanda kebanjiran dan sebagian yang percaya selamat dengan mengikuti bahtera Nabi Nuh. 
Analisis nilai religi yang dilihat sebagai rasa takjub akan keagungan Tuhan dalam Ciumlah Aku di Ujung Subuh Karya Hamzah Puadi Ilyas

[1] Ya, Tuhan. Harummu tercium Durjana. Ia jatuh cinta setengah mati kepadamu. Ia datang menemui ayah dan mengatakan akan menikahimu dan menjadikanmu istri kesepuluh. Ia tak peduli, walau ayah mengatakan bahwa engkau tak bisa bicara. Ia telah gelap mata. Kecantikanmu telah menutupi kecacatanmu. (CAUS, 2008:89)

Kutipan di atas menunjukan bahwa penulis menjelaskan nilai religi sebagai rasa takjub akan keagungan Tuhan yaitu adanya rasa takjub mengenai aroma yang tercium seperti durjana. Hal ini menandakan bahwa dirinya takjub dengan durjana atau surga yang memiliki aroma yang sangat indah.

[2]Bagus jingga. Kuncilah pintu kamar. Berjalan ke arah jendelah dan bukalah daun jendela itu. Lihatlah ke langit. Ada bulan, Jingga. Dan rasakan sinarnya menyentuh tubuhmu. "Hangat sekali" kata batinmu. Tunggulah beberapa saat. Kosongkan hatimu. Lihatlah! Perhatikanlah sinarnya yang lambat laun pudar. "Apa yang terjadi?" engkau bertanya dan bingung. .(CAUS, 2008:91)

Kutipan di atas menunjukan bahwa penulis menjelaskan nilai religi sebagai rasa takjub akan keagungan Tuhan yaitu adanya rasa takjub mengenai penciptaan Tuhan terhadap alam semesta. Hal ini menandakan bahwa dirinya takjub terhadap ciptaan tuhan seperti mampu menciptakan langit, dan dilangit itu pula ada bulan, serta sinarnya pun bisa dirasakan oleh manusia.

[3] "Engkau benar, Istriku."

"Ya, kampung ini sedang diberi peringatan oleh Tuhan. Namun kebanyakan penghuninya tidak sadar....." (CAUS, 2008:147)

Kutipan di atas menunjukan bahwa penulis menjelaskan nilai religi sebagai rasa takjub akan keagungan Tuhan yaitu adanya rasa takjub mengenai peringatan dari Allah SWT. Hal ini menandakan bahwa dirinya takjub dengan kekuatan dan kekuasaan Allah SWT, jika memang Allah SWT berkehendak dan memberikan peringatan maka tidak ada satupun yang bisa lari dari peringatan tersebut.

Analisis nilai religi yang dilihat sebagai getaran hati nurani pribadi dalam Ciumlah Aku di Ujung Subuh Karya Hamzah Puadi Ilyas

[1] Laela terkejut, merona bahagia dengan bibir bagai bunga merekah, "Ya, Tuhan, Mas Har, indah sekali." Tak lama kemudian cincin itu segera melingkar di jari manis Laela. (CAUS, 2008:6)

Kutipan di atas menunjukan bahwa penulis menjelaskan nilai religi sebagai getaran hati nurani pribadi yaitu adanya getaran dari hati yang paling dalam mengenai peristiwa yang sedang dialaminya. Hal ini menandakan bahwa dirinya memiliki getaran perasaan hati yang paling dalam ketika diberikannya cincin tersebut dan melingkari jari manisnya. Ketika itu pula ia mengucapkan syukur yang paling dalam dan tulus kepada Allah swt.

[2]Malam-malam berikutnya sering terdengar suara tangisan Izan yang menyayat hati. Sebagai seorang wanita yang telah melahirkan, saya tahu Izan lapar. Ingin rasanya saya keluar, mengetuk pintu rumah wanita tu, dan memberi Izan susu. Tapi lagi-lagi saya ngeri dengan tatapan ibunya yang bagai memancarkan api. (CAUS, 2008:74)

Kutipan di atas menunjukan bahwa penulis menjelaskan nilai religi sebagai getaran hati nurani pribadi yaitu adanya getaran dari hati yang paling dalam mengenai peristiwa yang sedang 
dialaminya. Hal ini menandakan bahwa dirinya memiliki getaran perasaan hati yang paling dalam ketika mendengar tangisan Izan dan ingin segera memberikannya susu, tapi hal itu tak mungkin karena orang tuanya tidak mungkin mengizinkannya.

[3] "Kamu mau kan, Anakku?" Tanya Pak Haji. "Setelah tamat, kamu bisa membangun pesantren di tanah Ayah. Di sini orang-orang makin jauh dari agama." (CAUS, 2008:139)

Kutipan di atas menunjukan bahwa penulis menjelaskan nilai religi sebagai getaran hati nurani pribadi yaitu adanya getaran dari hati yang paling dalam mengenai peristiwa yang sedang dialaminya. Hal ini menandakan bahwa dirinya memiliki getaran perasaan hati yang paling dalam ketika menyuruh anaknya kelak membangun pesantren untuk membantu masyarakat sekitarnya yang kurang akan agama.

Analisis nilai religi yang dilihat sebagai sikap personal yang merupakan misteri bagi orang lain dalam Ciumlah Aku di Ujung Subuh Karya Hamzah Puadi Ilyas

[1] Malam makin larut. Suja melepaskan tangannya dari kepala Surya. Ia lalu Berdiri dan bergerak menuju sajadah yang terbentang di pojok ruangan. Ia ingin kembali bersujud, dalam malam yang hanya ditemani cahaya lilin. (CAUS, 2008:15)

Kutipan di atas menunjukan bahwa penulis menjelaskan nilai religi sikap personal yang merupakan misteri bagi orang lain yaitu adanya sikap atau perbuatan/sikap seseorang dalam menjalani aktivitas sehari-harinya sesuai dengan tuntutan agama. Hal ini menandakan bahwa ia sennatiasa beribadah dan bersujud pada meski sudah malam hari.

[2] Tiba-tiba suara Haji Jamil terdengar keras sambil membaca Istigfar, diikuti oleh beberapa lelaki lain. Saya segera keluar kamar sambil mendekap Izan. Saat berjalan beberapa langkah ke pintu kamar mandi badan saya bergemetar, jantung saya berhenti berdetak, dan tengkuk saya seperti disiram air es. Bila tak ada tembok, mungkin saya telah jatuh terduduk. Saya melihat seorang wanita tergantung dengan lidah menjulur dan mata mendelik. Ada wajah setan. (CAUS, 2008:79)

Kutipan di atas menunjukan bahwa penulis menjelaskan nilai religi sikap personal yang merupakan misteri bagi orang lain yaitu adanya sikap atau perbuatan/sikap seseorang dalam menjalani aktivitas sehari-harinya sesuai dengan tuntutan agama. Hal ini menandakan bahwa ia senantiasa beribadah dengan senantiasa mengucapkan "Istigfar....." ketika mendapatkan atau mendengar berita tidak baik/terkena musibah.

[3] Pak Haji kembali memainkan tasbih di tangannya. Bibirnya bergerak-gerak dan sesekali matanya terpejam. Suara anak-anak yang melantunkan Juz Amma mendengar berbarengan, mengisi relung-relung mushola berdinding kayu. Warna putihnya telah mulai memudar. Pada awalnya suara anak itu seperti enggan keluar karena masih tersisa keinginan untuk tidur, tapi lama-kelamaan suara mereka makin nyaring. (CAUS, 2008:137)

Kutipan di atas menunjukan bahwa penulis menjelaskan nilai religi sikap personal yang merupakan misteri bagi orang lain yaitu adanya sikap atau perbuatan/sikap seseorang dalam menjalani aktivitas sehari-harinya sesuai dengan tuntutan agama. Hal ini menandakan bahwa ia senantiasa beribadah dengan senantiasa mengucapkan dzikir dan melantunkan/membacakan Juz Amma. 


\section{Karya Hamzah Puadi Ilyas}

[1] "Aku tidak mau, nanti sifatku seperti anjing." Kata hatinya berucap. Tapi, kemudian anjing itu seolah berkata lagi bahwa ia sebenarnya bukan anjing biasa, melainkan penjelmaan malaikat yang memang diutus untuk membantu manusia yang sedang dalam kesulitan, apalagi jika manusia itu baik dan suka member makan hewan yang keleaparan. (CAUS, 2008:42)

Kutipan di atas menunjukan bahwa penulis menjelaskan nilai religi sebagai intimidasi jiwa yaitu adanya pemikiran yang mendalam mengenai pemikiran yang biasa terjadi. Jika, ia membunuh anjing, maka sifat dan tingkah lakunya akan berubah seperti anjing. Hal ini yang mendasari seseorang memiliki pemikiran/intimidasi jiwa dari segi karma.

[2] "Aku tidak mau, nanti sifatku seperti anjing." Kata hatinya berucap. Tapi, kemudian anjing itu seolah berkata lagi bahwa ia sebenarnya bukan anjing biasa, melainkan penjelmaan malaikat yang memang diutus untuk membantu manusia yang sedang dalam kesulitan, apalagi jika manusia itu baik dan suka member makan hewan yang keleaparan. (CAUS, 2008:42)

Kutipan di atas menunjukan bahwa penulis menjelaskan nilai religi sebagai intimidasi jiwa yaitu adanya pemikiran yang mendalam mengenai pemikiran yang biasa terjadi. Jika, ia membunuh anjing, maka sifat dan tingkah lakunya akan berubah seperti anjing. Hal ini yang mendasari seseorang memiliki pemikiran/intimidasi jiwa dari segi karma.

[3] "Aku Ia ingin mati di tengah malam agar jiwanya dapat melayang ke langit dalam kegelapan yang tenang. Ia ingin segera menemui Sang Pencipta, untuk menanyakan kenapa ia tidak menemukan kebahagiaan di dunia ini. Apakah kebahagiaan hanya untuk beberapa orang saja? Atau apakah ia telah dikutuk oleh ketidakberuntungan? Ia ingin mempertanyakan hal ini pada Tuhan. (CAUS, 2008:53)

Kutipan di atas menunjukan bahwa penulis menjelaskan nilai religi sebagai intimidasi jiwa yaitu adanya pemikiran yang mendalam mengenai pemikiran yang biasa terjadi. Jika, ia bunuh diri di tengah malam maka ia dapat melayang ke langit dalam kegelapan yang tenang sehingga ia bisa menanyakan kepada Tuhan mengapa di dunia ini ia hidup dengan ketidakberuntungan. Hal ini yang mendasari seseorang memiliki pemikiran/intimidasi jiwa tersebut.

Berdasarkan hasil analisis nilai religius pada cerpen Ciumlah Aku di Ujung Subuh Karya Hamzah Puadi Ilyas tersebut, dapat diketahui bahwa nilai religius yang muncul dari beberapa aspek seperti kepercayaan kepada Allah, rasa takjub akan keagungan Tuhan, getaran hati nurani pribadi, sikap personal yang merupakan misteri bagi orang lain dan intimidasi jiwa. Aspek-aspek religius tersebut berkembang dalam setiap kalimat-kalimat cerpen secara menyeluruh dengan situasi cerita yang tepat dalam cerpen tersebut.

Nilai religius dalam cerpen Ciumlah Aku di Ujung Subuh Karya Hamzah Puadi Ilyas tersebut diketahui terdapat nilai religius dalam aspek kepercayaan kepada Allah meliputi percaya adanya malaikat, hari kiamat, bahtera nabi, dan percaya al-Quran dan hadis; nilai religius dalam aspek rasa takjub akan keagungan Tuhan meliputi takjub akan aroma durjana, kekuasaan tuhan, dan penciptaan alam semesta; nilai religius dalam aspek getaran hati nurani pribadi meliputi getaran hati akan syukur, tangisan peristiwa, ingatan dulu, dan cita-cita; nilai religius dalam aspek sikap personal meliputi sikap beribadah, bersujud, beristigfar, berdzikir, dan membaca al-Quran/juz-amma; dan nilai religius dalam aspek intimidasi jiwa meliputi intimidasi jiwa dari karma, proses inti kematian, 
dan proses pencabutan nyawa.

Pengarang yang baik tidak hanya menceritakan tentang percintaannya saja. Namun, dalam hal keagamaan juga perlu ditampilkan untuk memengaruhi pembaca. Cerpen yang terdapat nilai religius akan membuat hati pembaca tersentuh untuk mengingat dosa-dosa yang telah diperbuat dan meningkatkan keimanannya (Sari, 2019:3-4). Dalam hal ini, iman dan taqwa seseorang dapat diaktualisasikan dalam cerpen melalui cerita atau peristiwa-peristiwa keagamaan, seperti sikap, dialog, monolog, maupun fenomena yang terjadi dalam cerpen.

Berdasarkan hasil penelitian ini dapat diketahui juga bahwa nilai religius yang paling banyak muncul dalam cerpen Ciumlah Aku di Ujung Subuh Karya Hamzah Puadi Ilyas tersebut yaitu sikap personal. Menurut Poerwodarminto dalam Suharyat (2019), sikap personal adalah perbuatan yang didasari oleh keyakinan berdasarkan norma-norma yang ada di masyarakat dan biasanya norma agama. Namun demikian perbuatan yang akan dilakukan manusia biasanya tergantung apa permasalahannya serta benar-benar berdasarkan keyakinan atau kepercayaannya masing-masing.

Sikap seseorang melibatkan pengetahuan tentang sesuatu, namun perasaan dan emosi inilah yang menjadi kunci pengendalian dari sikap itu sendiri (Ellis dalam Suharyat, 2019). Jadi sikap itu berhubungan dengan perasaan seseorang terhadap obyek bukan tindakan, dimana perasaan ada kalanya positif dan ada kalanya negatif. Dengan demikian, nilai religius dapat dikatakan sebagai sikap yang mencerminkan diri seseorang terhadap perilaku yang digunakannya dalam bentuk citacita, tingkah laku, dan tindakkan sehari-hari (Suharni, 2019; Zuchdi, 1995). Sikap seseorang terhadap suatu hal tertentu dipengaruhi oleh ajaran-ajaran yang dianut atau yang melatarbelakangi seseorang tersebut sebagai pengalaman hidupnya (Muhtadi \& Al, 2006). Sikap tersebut dapat dimanifestasikan ke dalam beberapa bentuk seperti sikap beribadah, sopan santun, saling menghormati, dan lain-lain (Leha, 2017:269-273).

Untuk menunjukan adanya sikap religius, dapat dilakukan melalui beribadah. Setiap manusia melakukan ibadah untuk menunjukkan rasa syukur dan taqwa (Leha, 2017:269). Ibadah dilakukan sebagai pengabdian ritual sebagaimana diperintahkan dan diatur dalam al-Quran dan sunah. Dengan demikian, sikap religius seseorang dapat ditunjukkan dengan ibadah, sebab ibadah merupakan ketaatan manusia kepada Tuhan yang diimplementasikan dalam kegiatan sehari-hari misalnya sholat, puasa, zakat, dan lain sebagainya (Dasir, 2018:5: Saputri \& Nurizzati, 2019).

Sopan santun juga menjadi salah satu sikap yang menunjukkan adanya nilai religius. Sopan santun dapat dikatakan suatu nilai yang berupa aturan tidak tertulis dalam masyarakat namun diyakini untuk dijalankan, namun jika melanggar akan dikenakan sanksi moral. Dengan demikian, sopan santun adalah perilaku yang menjunjung tinggi nilai-nilai yang harus dilakukan dalam berhubungan dengan sesama manusia agar tercipta hubungan yang damai dan sejahtera (Leha, 2017:270; Roshita, 2015).

Manusia dalam menjalani kehidupan tidak bisa hidup sendiri, melainkan perlunya ada interaksi dengan sesamanya. Efek dari interaksi ini ialah adanya saling menghormati. Sikap saling hormat adalah kebiasaan yang dilakukan seharihari selalu memperhatikan nilai-nilai moral, nilai-nilai agama, sosial, emosional, dan kemandirian (Anggreini, 2013:2: Fajarini, 2014).

Analisis nilai-nilai religi dalam cerpen Ciumlah Aku di Ujung Subuh Karya Hamzah Puadi Ilyas, serta implikasinya dalam pembelajaran apresiasi sastra di SMA memberikan implikasi bagi siswa dan guru khususnya guru yang mengajarkan sastra. Implikasi bagi guru yaitu menjadikan masukan dan wahana baru dalam pembelajaran sastra. Selain itu, juga memberikan implikasi bagi siswa yaitu dengan memahami nilai religi dalam apresiasi sastra khususnya cerpen. 
Belajar mengenai nilai religi dalam cerpen berarti mencoba membina agar anak memiliki kesanggupan untuk mengidentifikasi, menganalisis, serta merelevansikan nilai-nilai yang terdapat di dalam cerpen dengan kehidupan sebenarnya. Menganalisis nilai religi dengan sungguh-sungguh dapat menumbuhkan kepekaan dalam pikiran dan kepekaan perasaan yang baik terhadap cipta sastra melalui peran yang terdapat pada cerpen tersebut.

\section{SIMPULAN}

Berdasarkan hasil analisis nilai religius pada cerpen Ciumlah Aku di Ujung Subuh Karya Hamzah Puadi Ilyas didapati terdapat 19 temuan mengenai kepercayaan kepada Allah, 8 temuan mengenai rasa takjub akan keagungan Tuhan, 7 temuan mengenai getaran hati nurani pribadi, 21 temuan mengenai sikap personal, dan 5 temuan mengenai intimidasi jiwa. Aspek-aspek religius tersebut berkembang dalam setiap kalimat-kalimat cerpen secara menyeluruh dengan situasi cerita yang tepat dalam cerpen tersebut. Nilai religius dalam cerpen Ciumlah Aku di Ujung Subuh Karya Hamzah Puadi Ilyas tersebut diketahui terdapat nilai religius dalam aspek kepercayaan kepada Allah meliputi percaya adanya malaikat, hari kiamat, bahtera nabi, dan percaya al-Quran dan hadis; nilai religius dalam aspek rasa takjub akan keagungan Tuhan meliputi takjub akan aroma durjana, kekuasaan tuhan, dan penciptaan alam semesta; nilai religius dalam aspek getaran hati nurani pribadi meliputi getaran hati akan syukur, tangisan peristiwa, ingatan dulu, dan cita-cita; nilai religius dalam aspek sikap personal meliputi sikap beribadah, bersujud, beristigfar, berdzikir, dan membaca al-Quran/juzamma; dan nilai religius dalam aspek intimidasi jiwa meliputi intimidasi jiwa dari karma, proses inti kematian, dan proses pencabutan nyawa. Dapat disimpulkan bahwa nilai religius yang dominan dalam cerpen Ciumlah Aku di Ujung Subuh Karya Hamzah Puadi Ilyas yaitu sikap personal. Sikap personal adalah perbuatan yang didasari oleh keyakinan berdasarkan norma-norma yang ada di masyarakat dan biasanya norma agama.

\section{DAFTAR PUSTAKA}

Aminudin. (1990). Pengembangan Penelitian Kualitatif dalam Bidang Bahasa dan Sastra, Malang: Yayasan Asih, Asah, Asuh.

Anasrullah, A. (2018). Nilai-Nilai Religius pada Novel Ajari Aku Menuju Arsy Karya Wahyu Sujani. Stilistika: Jurnal Pendidikan Bahasa dan Sastra, 10(1).

Anggreini, D. (2013). Penerapan Metode Sosiodrama untuk Meningkatkan Perilaku Saling Menghormati Pada Kelompok A2 TK Mentari Nusa PG Lestari Nganjuk. PAUD Teratai, 2(3).

Dasir, M. (2018). Implementasi Nilai-Nilai Religius dalam Materi Pendidikan Agama Islam dan Budi Pekerti Tingkat SMA/SMK Kurikulum 2013 (Master's thesis, Universitas Islam Indonesia).

Ellis, Robert S..Educational Psychology: a Problem Approach. NewYork:d. Van Nostrard Co.

Fajarini, U. (2014). Peranan kearifan lokal dalam pendidikan karakter. SOSIO-DIDAKTIKA: Social Science Education Journal, 1(2), 123-130.

Faizah, S., \& Bengat, A. (2017). Pemuatan Karakter Religius dalam Pembelajaran Menulis Cerpen sebagai Pengembangan Bahan Ajar untuk Siswa SMP Negeri 2 Ulujami Kabupaten Pemalang. TEKS, 2(1), 18-23.

Hidaya, N. B. N. (2018). Gambaran Perilaku Mazakon Pada Tokoh Kouichi Mizukoshi Dalam Drama Fukigen Na Kajitsu Karya Sutradara Naomi Kinoshita (Doctoral dissertation, Universitas Brawijaya).

Kurniawan, M. A. (2011). Kritik Sosial dalam Novel Menunggu Matahari Melbourne Karya Ramy Sylado: Tinjauan Sosiologi Sastra. Jurnal Bahastra, 26(1). 
Kesambamula, E., \& Semi, M. A. (2013). Nilai-Nilai Religius Islam dalam Novel Tania Karya Asye Saidra. Abstract of Undergraduate, Faculty of Education, Bung Hatta University, 2(6).

Leha, N. (2018, February). Kajian Nilai Religius pada Madihin Karya John Tralala. In Prosiding Seminar Nasional Bahasa dan Sastra Indonesia (SENASBASA) (Vol. 1, No. 1).

Mansyur, U. (2018). Pemanfaatan Nilai kejujuran dalam Cerpen sebagai Bahan Ajar Berbasis Pendidikan Karakter.

Muhtadi, A., \& Al, L. (2006). Penanaman nilai-nilai agama islam dalam pembentukan sikap dan perilaku siswa Sekolah Dasar Islam Terpadu Luqman Al-Hakim Yogyakarta. Jurnal Penelitian dan evaluasi pendidikan, 1, 50-61.

Nurgiantoro, Burhan. (2013). Teori Pengajaran Fiksi. Yogyakarta: Gadjah Mada University Press. Nuroh, E. Z. (2011). Analisis Stilistika dalam Cerpen. PEDAGOGIA: Jurnal Pendidikan, 1(1), 2134.

Nuryatin, R. S. A. (2017). Nilai Pendidikan Dalam Antologi Cerpen Senyum Karyamin Karya Ahmad Tohari. Bahasa Dan Sastra Indonesia, 6(03), 314-322. https://ejournal.unnes.ac.id

Rondiyah, A. A., Wardani, N. E., \& Saddhono, K. (2017, June). Pembelajaran sastra melalui bahasa dan budaya untuk meningkatkan pendidikan karakter kebangsaan di era MEA (masayarakat ekonomi ASEAN). In Proceedings Education and Language International Conference (Vol. 1, No. 1).

Roshita, I. (2015). Upaya meningkatkan perilaku sopan santun melalui layanan bimbingan kelompok dengan teknik sosiodrama. Jurnal Penelitian Tindakan Bimbingan \& Konseling, 1(2).

Sari, F. N. (2019). Nilai-Nilai Religius dalam Kumpulan Cerpen Robohnya Surau Kami Karya AA Navis dan Implikasinya Terhadap Pembelajaran Sastra dI SMA.

Saputri, R., \& Nurizzati, N. (2019). Nilai-nilai Religius dalam Novel Ketika Tuhan Jatuh Cinta Karya Wahyu Sujani. Jurnal Bahasa dan Sastra, 7(3), 277-288.

Suharyat, Y. (2009). Hubungan antara sikap, minat dan perilaku manusia. Jurnal Region, 1(3), 119.

Sumardjo, Jakob \& K.M, Saini. (1991). Apresiasi Kesusastraan. Jakarta: Gramedia Pustaka Utama. Wulandari, R. A. (2015). Sastra dalam pembentukan karakter siswa. Jurnal Edukasi Kultura, 2(2), 63-73.

Zuchdi, D. (1995). Pembentukan sikap. Cakrawala pendidikan, 83690. 